\title{
高温における線材の定ひずみ塑性秝じり疲労*
}

\author{
藤 谷 景 三** 元 津 彰 夫** $^{* *}$
}

\section{The Low-Cycle Torsional Fatigue of Piano Wires under Constant \\ Strain Amplitude at Elevated Temperatures}

by

\author{
Keizo FuJITANI \\ (Faculty of Science and Engineering, Ritsumeikan University, Kycto) \\ and Akio GENTSU \\ (Kobe City Technical College, Kobe)
}

In this paper is presented a report of tests of constant strain low cycle torsional fatigue that were carried out on $0.81 \% \mathrm{C}$ piano wires at room temperature and at elevated temperatures $270^{\circ} \mathrm{C}$, $300^{\circ} \mathrm{C}$ and $400^{\circ} \mathrm{C}$ respectively, with a view to the investigation of the plastic fatigue phenomena. Three kinds of torsions were worked for the tests, completely reversed, fluctuating and pulsating, under the test speed of $1 \mathrm{rpm}$. The main results obtained are as follows.

(1) There is larger effect of temperature on the fatigue life than that of the mean strain. Let the strain amplitude stand as it is, there is longer fatigue life at $270^{\circ} \mathrm{C}$ and shorter fatigue life at $400^{\circ} \mathrm{C}$ than room temperature, the former case being considered to be the annealing effect.

(2) The time-strength diagram shows linear decrease in strain amplitude $\gamma_{a}$ against increase in the mean strain $\gamma_{m}$ which the latter represents the number of cycles from the initiation of macrocrack $N^{\prime}=50$ to its fracture $N=200$ or $N=1000$.

(3) The test result shows that there exists linear relationship between the total plastic strain $\gamma_{p}$. total and $N^{\prime}$ or $N$, when they are plotted on a $\log -\log$ scale. It is found also that the same relationship holds for the total hysteresis energy $W$, the not-total hysteresis $w^{\prime}$ and the strain amplitude $\gamma_{a}$. In the completely reversed tests, $\gamma_{p \text {.total }}$ and $W$ are defined as $\gamma_{p . \text { total }}=4 \sum_{n=1}^{N} \gamma_{p}+$ $\gamma_{m f}$ and $W=w \cdot N$, in which $\gamma_{p}$ and $\gamma_{m f}$ are the plastic strain amplitude and the mean strain just before fracture, respectively.

(Received Dec. 13, 1971)

\section{1 緒訔}

最近, 各種の機械要素や機械構造物は塑性領域での 応力あるいはひずみ状態で使用されることが少なくな い.このような場合，当然大きな繰返し塑性ひずみを 伴い, この塑性ひずみの蓄積が疲労寿命を支配するこ とは，すでに塑性領域での疲労現象を解明するにあた って, Coffin, Manson らをはじめ国の内外の多くの 研究者による種々の研究結果からも明らかである.

先に筆者の一人も種々の素炭鋼について主に塑性ね じり疲労試験を行ない, 疲労過程中の応力ーひずみの 関係と疲労寿命ならびに平均応力の影響などについて 探究してきた.しかし最近は高温のふん囲気の下で諸 機械が使用されることが多いので高温に和壮る塑性疲 労挙動も注目すべき問題の一つである.ところが，こ

* 原稿受理 昭和 46 年 12 月 13 日

** 正会員 立命館大学理工学部 京都市北区等持院北町

*** 正会員 神戸市立工業高等専門学校 神戸市垂水区舞子台
の種の研究報告は数少なく実際の設計に適用しらる段 階にはいたっていないよらである。また本実験に用い たピアノ線は, ある温度範囲では冷間引抜加工時に材 料の内部に生じた残留応力が減少して，じん性が失な われ疲労寿命が短くなるが, ある温度範囲では疲労寿 命が長くなることもある。

そこで本実験では, 各種の温度範囲に执いて, 平均 ひずみを種々変化させた場合について一連の定ひずみ 塑性ねじり疲労試験を実施した.これらの実験結果か ら,ここでは主として両振り疲労試験では塑性ひずみ の総和ならびにヒステリシスエネルギの総和と繰返し 数との関係, さらに平均ひずみを与文た場合にはひず み振幅ならびにヒステリシスエネルギと繰返し数との 関係を調べ各種温度に沶いても直線関係が存在するこ とを確かめた。また各種温度に和ける時間強度線図に ついても検討を加えた。な和，繰返し数としてはき裂 の発生が巨視的に認められるまでの繰返し数と破壊ま 
での繰返し数の両方について調べた。

\section{2 実験材料および実験方法}

実験に用いた材料は $0.81 \%$ Cを含有するピアノ線で， 直径 $5.5 \mathrm{~mm}$ の丸棒線材から数段の引拢き工程を経 て直径 $3 \mathrm{~mm}$ に仕上げたものである。そ先化学成分 および機械的性質をそれぞれ Table I おょび Table II に示す。また試験片は上述のごとく直径 $3 \mathrm{~mm}$ で標点 距離を $75 \mathrm{~mm}$ とした. 実験は容量 $200 \mathrm{~kg} \cdot \mathrm{cm}$ の静 ねじり試験機を用い, 回転速度は毎分 1 回転とした。 また高温試験に際しては円筒形の炉心にニクロム線を 巻いた電気炉を用いた。温度の制御は試験片試験部の 表面から $1 \mathrm{~mm}$ のころに熱電対をおき，あらかじめ 静止時における試験片表面の温度と設定筒所における

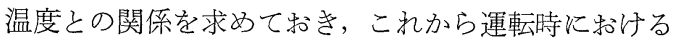
試験片の温度を推定した。 また試験片の標点距離全体 にわたって, 設定温度とほぼ等しく温度䛊差の僅少な ることを確認してから自動温度調節器により制御を行 なった. 試験条件は常温, $270^{\circ} \mathrm{C}, 300^{\circ} \mathrm{C}$, お上び $400^{\circ} \mathrm{C}$ の各温度に掠いてひずみ振幅 $\gamma_{a}$ は平均ひずみ $\gamma_{m}$ を 種々変えた場合, すなわち, $\gamma_{m}=0, \gamma_{a}=5 \gamma_{m}, \gamma_{a}=$ $3 \gamma_{m}, \gamma_{a}=\gamma_{m}, \gamma_{a}=0.6 \gamma_{m}$ および $\gamma_{a}=0.3 \gamma_{m}$ のそれ ぞれについて比較的大応力が作用する場合について, 定ひずみ塑性ねじり疲労試験を行なった。また応力な らびにひずみはそれぞれねじりモーメントならびにね じれ角より弾性式を用いて計算した。

Table I. Chemical compositions of the material (\%).

\begin{tabular}{c|c|c|c|c|c|c|c}
\hline $\mathrm{C}$ & $\mathrm{Mn}$ & $\mathrm{S}$ & $\mathrm{P}$ & $\mathrm{S}$ & $\mathrm{Cu}$ & $\mathrm{N} 1$ & $\mathrm{Cr}$ \\
\hline 081 & 045 & 023 & 0012 & 0.005 & 0.07 & 0.02 & 002 \\
\hline
\end{tabular}

Table II. Mechanical properties of the material

\begin{tabular}{c|c|c}
\hline $\begin{array}{c}\text { Tensile strength } \\
\sigma_{B}\left(\mathrm{~kg} / \mathrm{mm}^{2}\right)\end{array}$ & $\begin{array}{c}\text { Torsional strength } \\
\tau_{B}\left(\mathrm{~kg} / \mathrm{mm}^{2}\right)\end{array}$ & $\begin{array}{c}\text { Charpy impact value } \\
\left(\mathrm{kg} \cdot \mathrm{m} / \mathrm{cm}^{2}\right)\end{array}$ \\
\hline 1736 & 1400 & 109 \\
\hline
\end{tabular}

\section{3 実験結果および考察}

\section{$3 \cdot 1$ 定ひずみ両振り塑性ねじり疲労試験の場合}

Fig. 1 は線材の静的稀じり試験の結果を縦軸にせん 断力 $\tau$, 横軸にせん断ひずみてをとって示したもので ある.Fig. 2 は定ひずみ両振り塑性ねじり疲労試験の 結果を縦軸にひずみ振幅 $\gamma_{a}$, 横軸に点線でき裂の発 生が巨視的に認められるまでのひずみ繰返し数 $N^{\prime}$ (以 後き裂発生繰返し数とよぶ）と実線で破壊までのひず み繰返し数 $N$ をとって示したものである。なお， $N^{\prime}$ は常温では肉眼炕るるき裂の発生点をとり，これはひ ずみ繰返し試験中に応力振幅が急減しはじめる点と一 致したので, 高温でもこのひずみ繰返し試験中に応力 振幅が急隇しはじめる点をき裂の発生点とみなした。

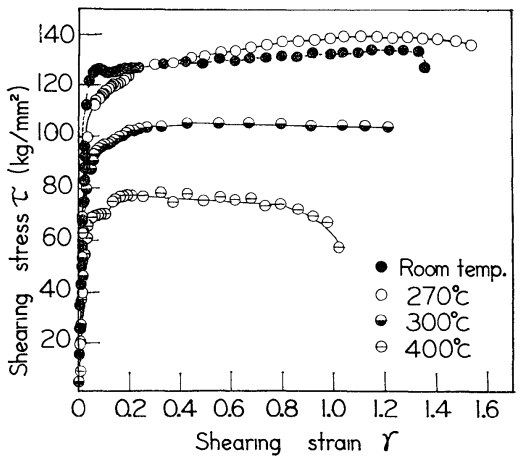

Fig. 1. Results of static torsional test.

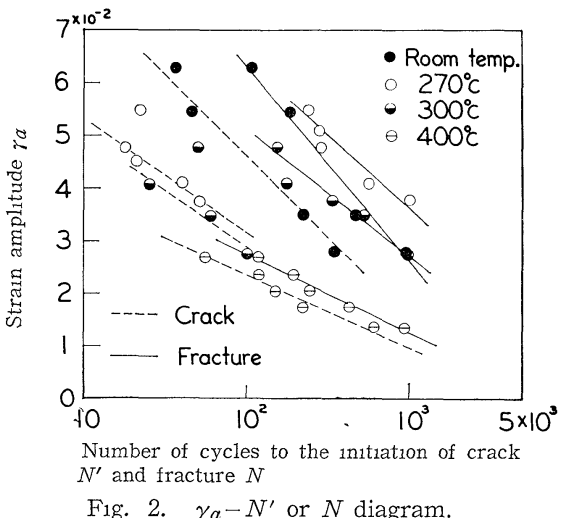

図より明らかなように，同一ひずみ振幅に対してき裂 発生繰返し数で整理した場合, 常温の場合が長い, 疲労 寿命を示し, $270^{\circ} \mathrm{C}, 300^{\circ} \mathrm{C}$ 扝よび $400^{\circ} \mathrm{C}$ の順㑔㐸疲 労寿命が短くなる傾向が現われた。 また破壞までの繰 返し数で整理した場合, $270^{\circ} \mathrm{C}$ の場合が長い疲労寿命 を示し, 常温, $300^{\circ} \mathrm{C}$ 拈よび $400^{\circ} \mathrm{C}$ 順に順次疲学寿命 が短くなる傾向が現われ，点線抒よび実線の常温牧よ び $270^{\circ} \mathrm{C}$ の場合に異なった傾向を示した。このことは, $270^{\circ} \mathrm{C}$ の場合には青熱ぜい性の温度範囲にあり, 繰返 し応力が作用すると温度と応力の重畳作用, すなわら, せい熱ぜい性の効果とさらに応力が加わる応力時効と によって材質が強化されたためであり， $400^{\circ} \mathrm{C}$ の場合 には高い温度のために冷間引抜加工時に材料の内部に 生じた残留応力が減少して疲労強度が低下したためで ある。

Fig. 3 はFig. 2 のひずみ振幅 $\gamma_{a}$ Fig. 1 の $\tau$ - 線 四からそれ坟応する応力振幅 $\tau_{a}$ に書き直して表わ したものである. 図のように点線, 実線とも常温では 長寿命を示し, $270^{\circ} \mathrm{C}, 300^{\circ} \mathrm{C}$ 抢よび $400^{\circ} \mathrm{C}$ 順に疲労 寿命が短くなり, Fig. 2 の実線の場合とは多少異なっ た傾向が現わ机た。このよらに実線に打いて $270^{\circ} \mathrm{C}$ りも常温の場合が長寿命を示したのは，Fig. 1 から明 らかなように降伏点の近傍では同一せん断ひずみに対 して高いせん断応力を示しているからである。 


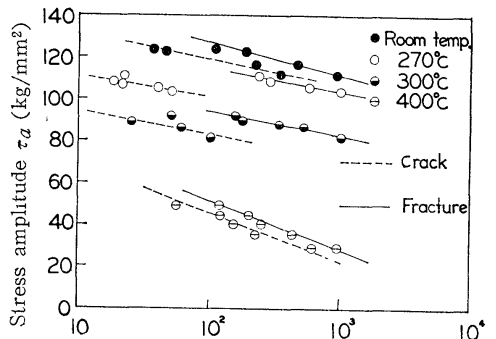

Number of cycles to the initiaion of crack $N^{\prime}$ and fracture $N$

Fig. 3. $\tau_{a}-N^{\prime}$ or $N$ diagram.

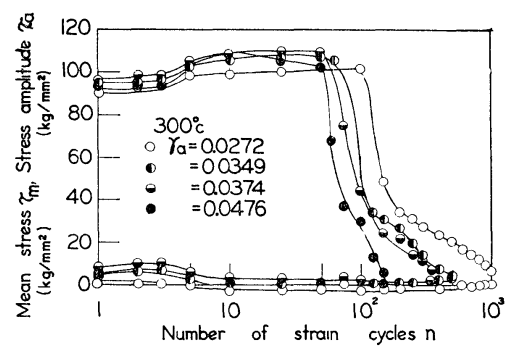

Fig. 4. Variations of stress amplitude and mean stress with number of strain cycles.

Fig. 4 は縦軸に応力振幅 $\tau_{a}$ と平均応力 $\tau_{m}$, 横軸 にひずみ繰返し数 $n$ をとってひずみ繰返し試験中に試 験片に作用する応力の変化の一例を $300^{\circ} \mathrm{C}$ の場合につ いて示したものである. 図より応力振幅の変化は 270 ${ }^{\circ} \mathrm{C}, 400^{\circ} \mathrm{C}$ の場合と同様に繰返し開始後まもなく増加 し，常温では繰返し開始後まもなく減少したのちいず れもわずかの間一定值を保ちき裂発生と同時に急激に 減少して破壊にいたっている。これらの繰返し初期の 応力振幅の増加ならびに減少は材料の硬化拉よび軟化 を示すものである。また破壊までの同一疲労寿命に対 して, き裂発生繰返し数は $400^{\circ} \mathrm{C}$ の昜合が他の温度に 比べて最も長く，き裂発生から破壊むでの繰返し数は $270^{\circ} \mathrm{C}$ の場合が最も長く, $400^{\circ} \mathrm{C}$ 場合が最も短くあら われた．これらは前述と同じ理由による. 繰返し数に 対する平均応力の変化の様子は試験片に作用するひず み振幅预よび試験温度によっては影響は少なく顕著に 現われなかった。

Fig. 5 は縦軸にき裂発生ならびに破壊末での塑性ひ ずみの総和 $\gamma_{p \text {.total }}=4 \sum_{n=1}^{N^{\prime}, N} \gamma_{p}+\gamma_{m f}$, 横軸に点線でき裂 発生繰返し数 $N^{\prime}$ と実線で破壊までの繰返し数 $N$ との 関係を各温度について両対数目盛りに図示したもので ある.ここに $\gamma_{p}$ は各サイクルに打ける塑性ひずみ振 幅, $\gamma_{m f}$ は破壊直前の平均ひずみである. 図より明ら かなようにこれらの関係は定応力両振り塑性ねじり 疲労試験でえられた結果と同様にほぼ直線関係が成り 立った. これらの関係を $\gamma_{p . t o t a l}=C \cdot N^{\alpha}$ なる式で表 わせば図示のような定数 $\alpha, C$ の值がえられ，各温度 によってそれぞれ異なった值を示した。すた塑性ひず

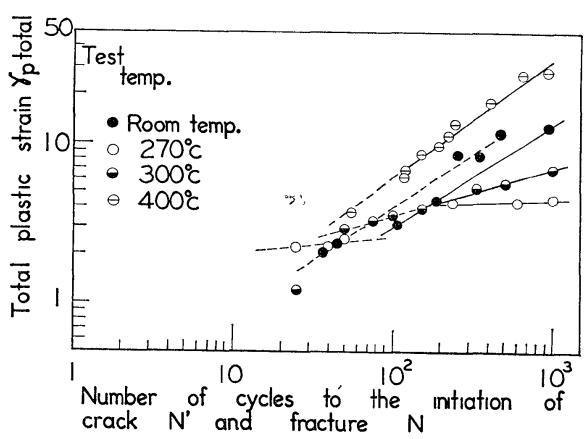

Fig. 5. Relations between total plastic strain and number of cycles to the initration of crack or fracture.

みの総和は同一繰返し数に対しては点線抒よび実線の 場合ともほぼ $400^{\circ} \mathrm{C}$ ，常温， $300^{\circ} \mathrm{C}$ および $270^{\circ} \mathrm{C}$ の順に 順次減少する傾向にある。塑性ひずみの総和が $400^{\circ} \mathrm{C}$ の場合他の温度に比べて大きく現われたのは，前述の ように破壊までの同一疲労寿命に対しては, 他の温度 に比べてき裂発生までの繰返し数が最も長く，き裂発 生から破壊までの繰返し数が最も短く，乙かも試験片 に作用する同一応力振幅に対して 1 サイクルあたりの 塑性ひずみ振幅が大きくなるためである。これに対し て塑性みずみの総和が $270^{\circ} \mathrm{C}$ の場合他の温度に比べて 小さく現われたのは，破壞までの同一疲労寿命に対し てき裂発生繰返し数が他の温度に比べて短く，き裂発 生から破壞までの繰返し数が長く，き裂発生と同時に 急激に塑性ひずみ振幅が減少するためである.

Fig. 6 は縦軸にき裂発生ならびに破壞までのヒステ

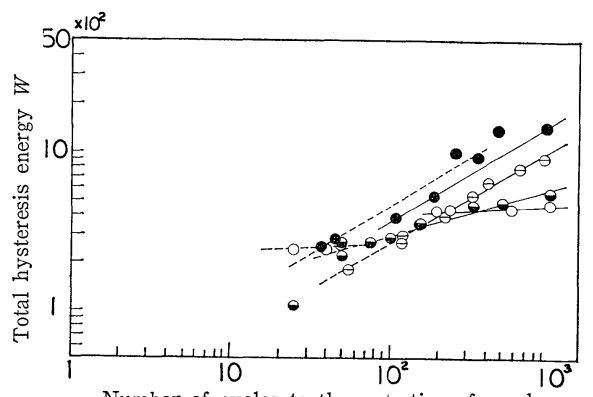

Number of cycles to the initiation of crack $N^{\prime}$ and fracture $N$

\begin{tabular}{c|c|c}
\hline \multirow{2}{*}{ Test temp. } & Crack & Fracture \\
\cline { 2 - 3 } & ----- & - \\
\cline { 2 - 3 } & $W=C \cdot N^{\prime \alpha}$ & $W=C \cdot N^{\alpha}$ \\
\hline $\begin{array}{r}\text { Room } \\
\text { temp. }\end{array}$ & $=0.218 N^{\prime 0.608}$ & $=0215 N^{0.618}$ \\
\hline$\bigcirc \quad 270^{\circ} \mathrm{C}$ & $=208 N^{\prime 0054}$ & $=3.00 N^{0068}$ \\
\hline$\ominus 300^{\circ} \mathrm{C}$ & $=0.843 N^{\prime 0285}$ & $=0843 N^{0285}$ \\
\hline$\ominus 400^{\circ} \mathrm{C}$ & $=0.185 N^{\prime 0.583}$ & $=0.185 N^{0.583}$ \\
\hline
\end{tabular}

Fig. 6. Relations between total hysteresis energy and number of cycles to the initiation of crack or fracture. 


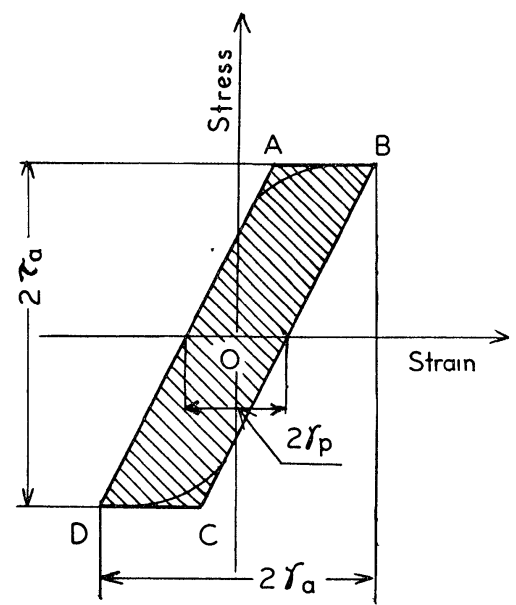

Fig. 7. Schematic diagram of hysteresis loop.

リシスエネルギの総和 $W$, 横軸に点線でき裂発生繰返 乙数 $N^{\prime}$ と実線で破壊むでの繰返し数 $N$ との関係を各 温度について両詨数目盛りに示したものである.き裂 発生ならびに破壊までのヒステリシスエネルギの総和 については，前報の方法と同様にFig. 7 の斜線で示し た応力振幅 $\tau_{a}$ と塑性ひずみ振幅 $\gamma_{p}$ の積から求まる 平行四辺形 $\mathrm{ABCD}$ の面積 $w=4 \tau_{a} \cdot \gamma_{p}$ を各サイクル ごとに近似的に求め，それをき裂発生ならびに破壊ま での繰返し数についてそれぞれ総和したもので ある、実際には，図の曲線で囲まれる面積で与 えられるから，この斜線で示したヒステリシス エネルギの值に補正係数を考慮に入れなければ ならない。しかし，この係数の值は疲労試験中 にヒステリシスループの形状が著しく変化しな いかぎりあまり変化を示さないから，ヒステリ シスエネルギの総和と繰返し数との関係を考察 するにあたって，その一般性は失なわれないる のと考学てよい。図の直線関係を $W=C \cdot N^{\alpha}$ なる式で表わせば図示のような定数 $\alpha, C$ の值 となり，Fig. 5 の塑性ひずみの総和で表わした場合と ほぼ近い值を示した。図よりWの值は同一繰返し数に 対して, 点線では $270^{\circ} \mathrm{C}$ を除いてほぼ常温, $300^{\circ} \mathrm{C}$ 打よ

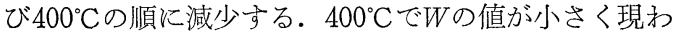
れたのは前述のFig. 3 のごとく応力振幅で表わした場 合，き裂発生までの疲労寿命が短いためである。また 実線ではほぼ常温， $400^{\circ} \mathrm{C} ， 300^{\circ} \mathrm{C}$ 打よび $270^{\circ} \mathrm{C}$ の順に 減少する.この場合常温でWの值が大さく現われたの は，Fig. 3 のごとく応力振幅で表わした場合破壊まで の疲労寿命が長いためである.

\section{$3 \cdot 2$ 平均ひずみを与えた場合}

Fig. 8 は平均ひずみを種々変化させて試験を行ない, 縦軸に最大せん断ひずみ、 $\gamma_{\max .}$, 横軸に点線でき裂発

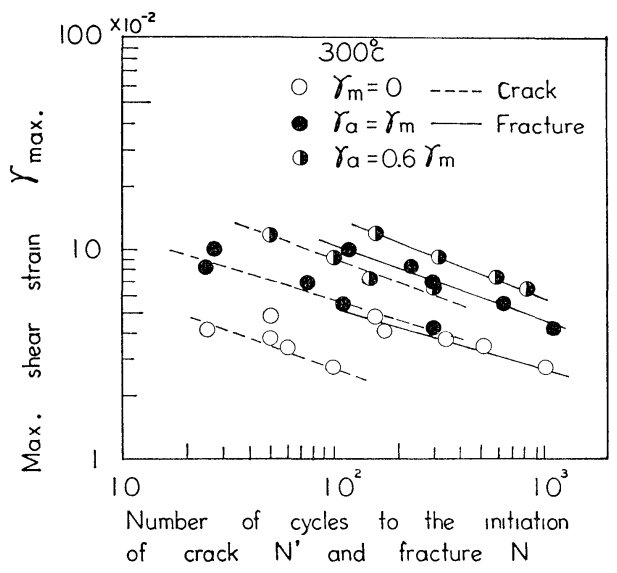

Fig. 8. $\gamma_{\text {max }}-N^{\prime}$ or $N$ diagram.

生繰返し数 $N^{\prime}$ と実線で破壊までの繰返し $N$ との関係 の一例を $300^{\circ} \mathrm{C}$ について表わしたものである。図にみ られるように点線, 実線とも平均ひずみの大なるほど 長い疲労寿命を示した. また常温, $270^{\circ} \mathrm{C}$ おる゙ $400^{\circ} \mathrm{C}$ についてもこれと同様なる傾向を現わした。いま，最 大せん断ひずみのかわりにひずみ振幅 $\gamma_{a}$ をとって表 わせば, Fig. 9, 10 に示すようになり，常温の場合は 400 ${ }^{\circ} \mathrm{C}$ と同様にき裂発生ならびに破壊までの繰返し数と も平均ひずみの影響が明りょらに現われずほぼ一本の 直線で表わされる。 $300^{\circ} \mathrm{C}$ の場合はき裂発生繰返し数

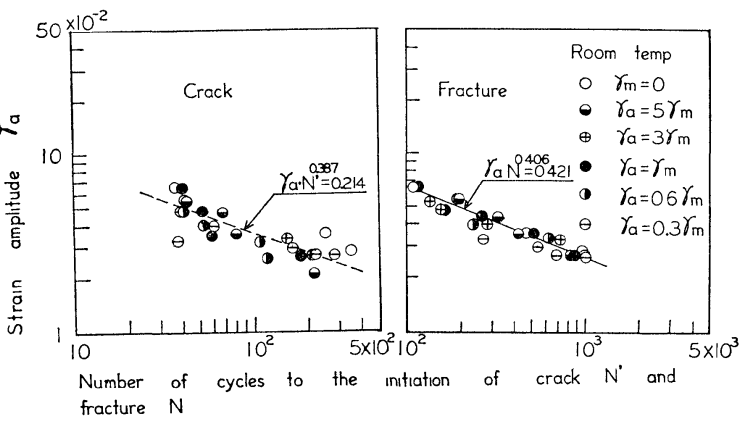

Fig. 9. $\gamma_{a}-N^{\prime}$ or $N$ diagram.

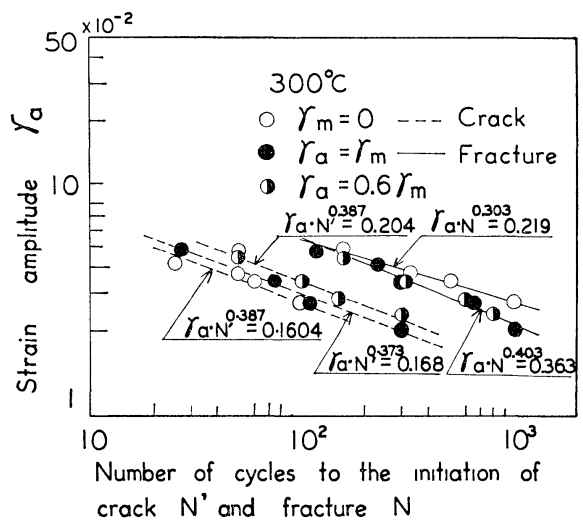

Fig. 10. $\gamma_{a}-N^{\prime}$ or $N$ diagram. 
で表わせば平均ひずみの大きいときと長寿命を示し， 破壊までの繰返し数で表わせば平均ひずみの影響はあ まり顕著にあらわれなかった。常温ならびに $300^{\circ} \mathrm{C}$ に ついてこれらの関係を $\gamma_{a} \cdot N^{\alpha}=C$ なる式で表わすと 図示の上らな定数 $\alpha, C$ の值が光られ，その值として はあまり大きい差はなかった。一般に定ひず反塑性疲 労試験に新いては塑性ひずみ幅 $\Delta \varepsilon_{p}$ と破壊までの繰返 乙数 $N$ との間には $\Delta \varepsilon_{p} \cdot N^{\alpha}=C$ が成り立ち, 高塑性域 では, この式の $\Delta \varepsilon_{p}$ をひずみ振幅 $\varepsilon_{a}$ で表わしても大 きな差はなく, この場合定教 はは活涪0.3〜0.8の值を とるものと論じられている。本寿験の場合にも図示の

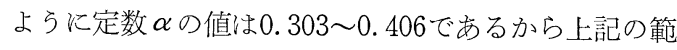
囲内に存在することがわかった。

各温度に扔いて定ひずみ片振り繰返し試験を行なら た結果を Fig. 11 と示す。図は縦軸にひずみ振幅 $\gamma_{a}$, 横軸倸点線でき裂発生繰返し数 $N^{\prime}$ と実線で破壊まで

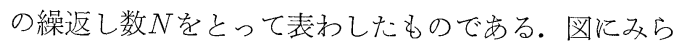
れるよう破壊までの寿命は $270^{\circ} \mathrm{C}$ が長く, き裂発生

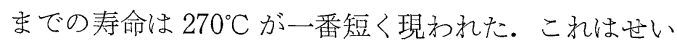

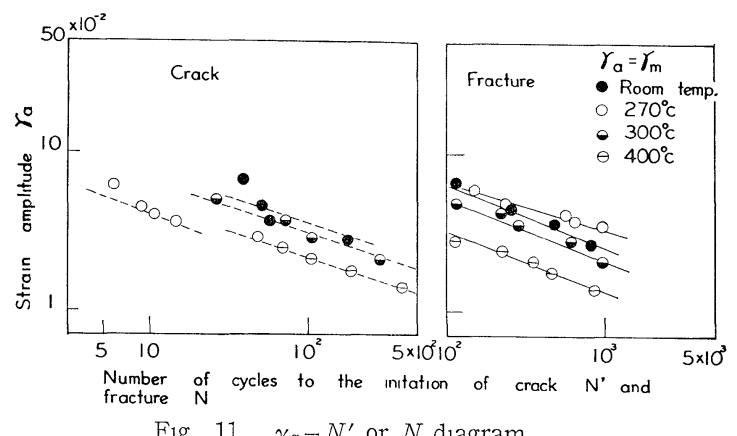

熱ぜい性の効果汇よる材料の硬化のためにき裂が早く 発生するが，同時にき裂先端近傍で著しい塑性変形が 生じ，硬化が起こるからき裂の進展が拈そくなったの である。

以上の実験結果を縌軸にひずみ振幅 $\gamma_{a}$, 横軸 に平均ひずみ $\gamma_{m}$ をとって表わしたものが Fig. 12 で, 図虫点線でき裂発生繰返し数 $N^{\prime}=50$ 回 と一点鎖線ならびそ実線でそれぞれ破壊までの 絽返し数 $N=200$ 回和よび $N=1000$ 回に打け る時間強度線図を描いたものである。図より明 らかなよらに同一疲労寿命に対しては, 河本ら が常温について行なった実験結果と同様に高温 に沶いてもひずみ振幅は平均ひずみの増加とと もに汪湆線的にわずかずつ減少する傾向を示 した。これらの現象は各温度について繰返し数 が 2 回目のヒステリシスエネルギいを面積計で 求めて縦軸に示し, 横軸に各平均ひずみ $\gamma_{m}$ を とって表わした Fig. 13 から明らかなように，

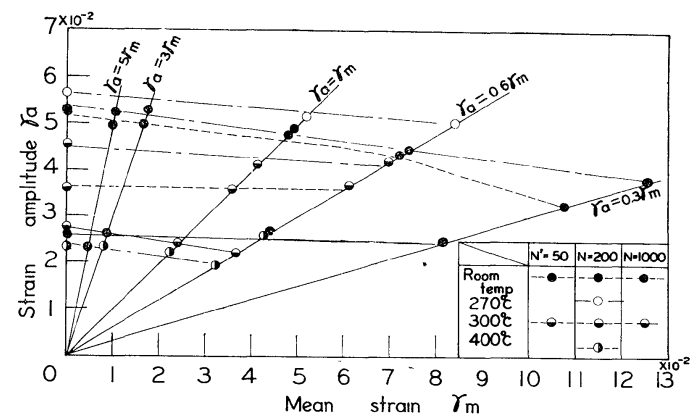

Fig. $12 \gamma_{a}-\gamma_{m}$ diagram

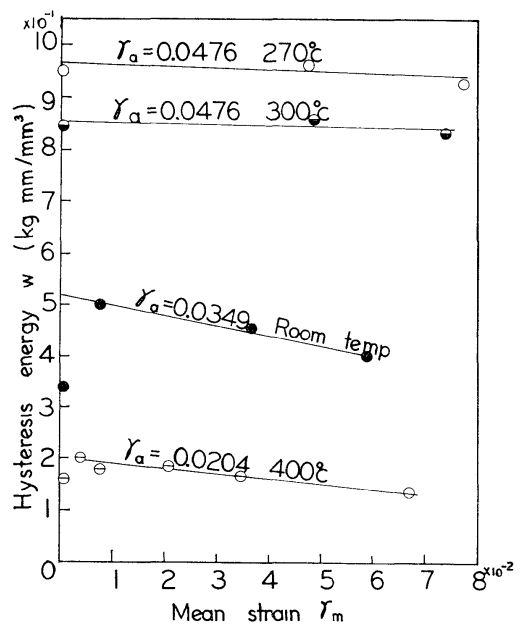

Fig. 13. $w-\gamma_{m}$ diagram.

1サイクルあたりのヒステリシスエネルギは平均ひず みの存在により少ないながらも直線的に減少するから である。

つぎに，前述の wと繰返し数との関係を常温および $300^{\circ} \mathrm{C}$ の場合について両対数目盛りで表わすと Fig. 14, 15のようになる。図の横軸は点線でき裂発生繰返し数

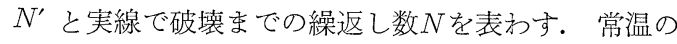
場合はき裂発生ならびに破壊までの繰返し数とも平均

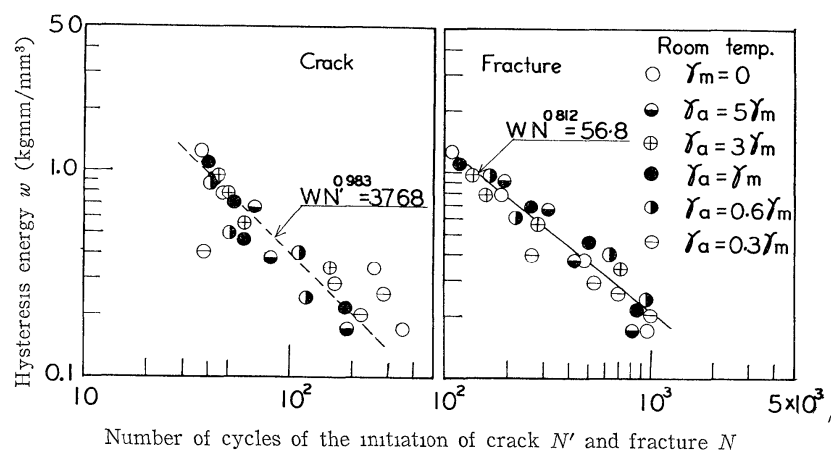

Fig. 14. Relations between hysteresis energy and number of cycles to the initiation of crack or fracture. 


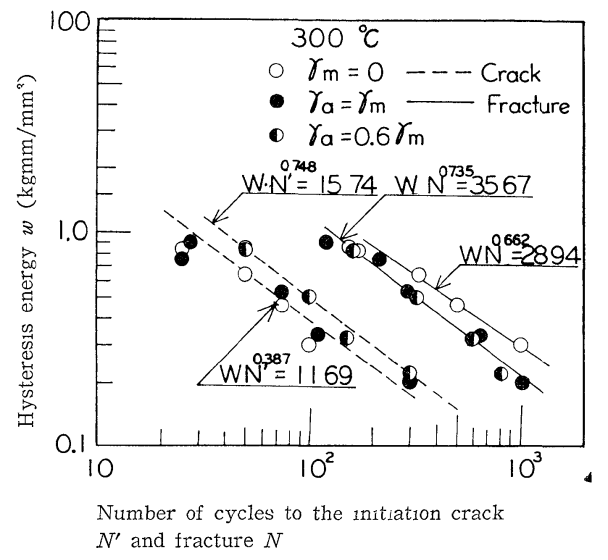

F1g. 15. Relations between hysteresis energy and number of cycles to the initiation of crack or fracture.

ひずみの影響が著しく現われずほぼ一本の直線で表わ される， $300^{\circ} \mathrm{C}$ の場合はき裂発生までの寿命は平均ひ ずみが大なるほど長寿命を示し, 破壊までの寿命は平 均ひずみの影響はあまり顕著に現われなかった。これ らの関係を $w \cdot N^{a}=C$ なる式で表わすと図示のよう な $\alpha, C$ の值が兄られた。

また参考むでに各温度において定ひずみ片振り繰返 乙試験を行なった結果をFig. 16 亿示す。図の縦軸は 繰返し数が 2 回目のヒステリシスエネルギ $w$, 横軸は 点線でき裂発生繰返し数 $N^{\prime}$ と実線で破壞までの繰返

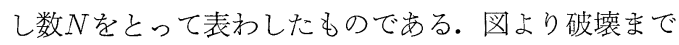

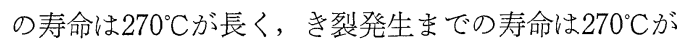
一番短く現われた。いずれについても, 温度による相 違は顕著である。ただし，ヒステリシスループが安定 したところでは， $300^{\circ} \mathrm{C}$ は常温よりもいくらか長寿命 側林たる傾向を示している。 また回転曲げ塑性疲 労試験泟いて定ひずみ試験では, 疲労寿命はヒステ リシスェネルギよりも温度が大きく影響を拉よぼすも のと判断されている. 本実験に扔いても Fig. 14〜16

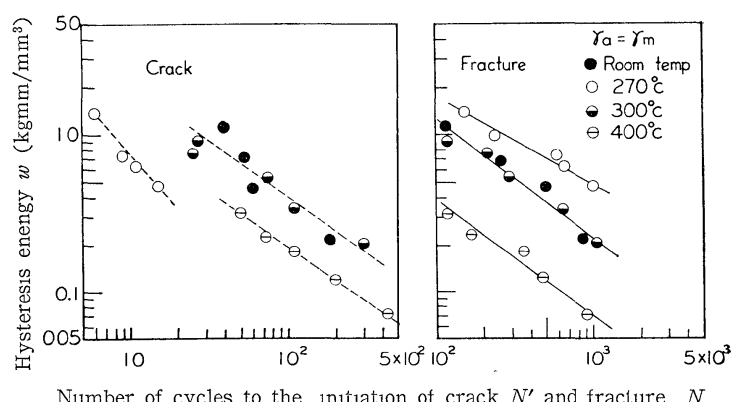

Fig. 16. Relations between hysteresis energy and number of cycles to the initiation of crack or fracture.
から同様にヒステリシスェネルギは温度による差は顕

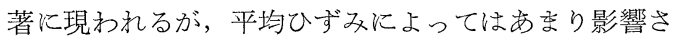
れなかった。よって，定ひずみ塑性ねじり疲学試験で は平均ひずみの存在上りも温度が大きく影響を拉上ぽ すことがわかる。

\section{4 結言}

$0.81 \%$ Cを含有するピアノ線を用いて繰返し速度 1 rpmの下で定ひずみ塑性ねじり疲労試験を行なった。 それらの試験条件としては常温, $270^{\circ} \mathrm{C}, 300^{\circ} \mathrm{C}$ おび $400^{\circ} \mathrm{C}$ 亿执いて両振り, 部分両振り, 片振りなどの平 均ひずみを与兄た場合について塑性疲労挙動を検討し た、な特、ひずみ繰返し数としてはき裂の発生が巨視

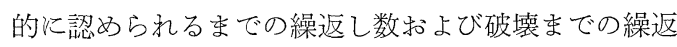
乙数の両方について調べた。

えられたおもな結果はつぎのと和りである。

(1) 定ひずみ両振り繰返し試験中に試験片に作用す る応力振幅の変化は, 常温では繰返し開始後まもなく 減少し, 高温では繰返し開始後まもなく増加したのち, いずれも核ぼ一定值を保ちき裂発生と同時に急減して 破壞にいたる．また，ひずる繰返し数に対する平均応 力の変化の様子は, 試験片作用するひずみ振幅拉よ び試験温度によっては影響は少なく顕著に現われなか った。

(2) 両振り繰返し試験では同一ひずみ振幅に対して 破壊までの繰返し数で整理した場合, $270^{\circ} \mathrm{C}$ が最大の 疲労寿命をもち, 以下常温, $300^{\circ} \mathrm{C}, 400^{\circ} \mathrm{C}$ の順浢く なる、またき裂発生繰返し数で整理した場合, 常温が

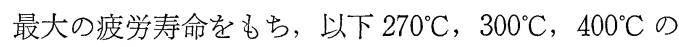
順湟くなる.

（3）平均ひずみを与光た繰返し試験枋いて，ひず み振幅之繰返し数で整理した場合, 平均ひずみの影響 は各温度とも顕著に現われなかった。あたヒステリシ スェネルギと繰返し数で整理した場合, ヒステリシス エネルギは平均ひずみにはあまり影響されず, 温度が 大きく影響を拉よぼすようである.

(4) 実験結果を両振り繰返し試験では, 塑性ひずみ の総和ならびとヒステリシスェネルギの総和と繰返し 数, 平均ひずみを与えた繰返し試験では, ひずみ振幅 ならびにヒステリシスエネルギと繰返し数との関係な どを両対数目盛りに表わすと, いずれも直線関係が成 り立つ.

（5）き裂発生繰返し数 $N^{\prime}=50$ 回と破壊までの繰返 乙数 $N=200$ 回抒よび 1000 回との時間強度線図に対 してひずみ振幅は平均ひずみの増加とともに注㯰線 的減少する傾向を示した。

(昭和46年 3 月 20 日 日本機㑘学会関西支部第46期定時総会講演会にて 講演) 


\section{参 考 文 献}

1）たとえば，河本 実，藤谷景三，日本材料試験協会第 11 期講演会前刷, 107 (1962); 河本 実, 藤谷景三, 第38 期日本機械学会通常総会講潰会前刷, No. 37, 118(1961); 河本 実, 藤谷景三, 山本英雄, 第40期日本機㳦学会全 国大会前刷, No. 77, 147 (1962).

2）藤谷景三，立命館大学研究所紀要， 5, 111(1960).
3）藤谷景三, 元津彰夫, 材料, 20, 1132 (1971).

4) 川田雄一, 河本 実, 横堀武夫, 宮川松男, “材料強度 工学ハンドブック”, p. 494 (1966) 朝倉書店

5) 河本 実, ほか 3 名, 日本材料学会第18期総会学術講演 会前刷, 122 (1969).

6) 河本 実, 伊吹幸彦, 中村秀夫, 日本機械学会論文集, 29, 1653 (1963).

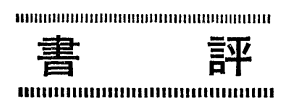

\title{
The Thermodynamics of Simple Materials with Fading Memory Springer Tracts in Natural Philosophy Volume 22
}

\author{
William Alan Day 著 \\ $(16 \mathrm{~cm} \times 24 \mathrm{~cm}, 134$ 頁，1972年，Springer-Verlag)
}

Truesde11 によって提唱され彼自身执よびその随伴者によって20年来急速に進展させられてきた連続体の有理 力学 (Rational Mechanics) の中で最も注目に価する画期的進展として, Coleman と Noll による減退記憶を もつ物質と Coleman による有理熱少学の導入が挙げられる. 前者は過去の履歴が現在に影響することを表わす ために，応力テンソルが過去から現在までの変形テンソルの沉関数として定式化され，後者はクラウジウス・デ ュエムの不等式を熱力学の第 2 法則の定式化としてとらえ, 物質の構成式を仮定する際の指針を与えるものであ り，多くの応用を生みだしている.

この本では上に述べたのとは異なる有理熱力学の定式化が記述されている. Coleman の熱力学はエントロピ 一の概念を始めより仮定しているのに対し，著者は応力テンソル，熱束ベクトル拉よび内部ェネルギの概念のみ を仮定する. 第 2 章ではそれらの量により基本となる熱力学不等式が構成され，第 3 章では目的とするエントロ ピーが定義されている。先ず平衡状態を考え, 二つの状態の間を結ぶクラウジウス積分の上限より平衡エントロ ピーが定義されている。さらに非平衡状態に歩を進め, クラウジウス・プランクの不等式より回復エントロピー が導出され，一般のエントロピーはこの両者の差として与えられている. 第 4 章では前章の仮定が熱弾性体，微 分型物質および粘弾性体に適用されているが，著者もいらごとく具体的なエントロピーの決定はきわめてむずか しい課題である．第 5 章では Coleman による有理熱力学の概要が簡単に紹介され，著者の方法と比較されてい る. 最終章では等温線型粘弾性体に対する熱力学からの制限について述べられている.

このように主内容は連続体の立場からェントロピーを他の巨視的量より決定する厚理を示したものであり，高 度に抽象的，数学的である。それゆ劣読者が連続体の熱的性質を具体的に解析する際この本を参照しても直接役 に立つ道具を読者に与えるものではない，第 1 章には，ベクトル，テンソル，平衡方程式等が単に紹介されてい るがこれのみではまったく不充分であり,この本の理解には有理力学の基礎概念と数学の知識が要求される.

(京都大学工学部 徳岡辰雄) 